press that name altogether. The next available name seems to be Capellinia Trinchese, 1874, an almost forgotten name revived under new misunderstandings by Pruvot-Fol (1954-Faune France $58: 420)$. She refers the species exiguus Alder \& Hancock to Capellinia and all other species with separate rows to the "true " Eubranchus. The figures given by Trinchese (1877-Aeolid. fam. Aff. tav. 24 Tergipes dorias, and tav. 25 $T$. capellinii) do not confirm this relationship. From the figure, $T$. capellinii is indistinguishable from the specimens of cingulatus Ald. \& Hanc. collected by me, and neither the number, the shape, nor the arrangement, of the cerata agree with exiguus.

The present situation at the generic level was well illustrated already by Thiele (1931-Handb. Moll. k. 1 : 452). He mentions Egalvina (type: viridula) with densely set cerata, and Eubranchus (type: tricolor) as having distinctly separate rows. This situation is the one generally accepted and therefore also the one I wish to stabilize as closely as possible, but the name tricolor is making trouble, as it, too, stands for the single species with cerata in clusters. That the name tricolor stands for complete confusion is illustrated once more by Mr. Heppell (who should not be blamed, however, as he only explains the confusion that he himself has been taught). Hence, I very much favour a solution where the highly ambiguous name tricolor is replaced by the unambiguous and generally known name viridula Bergh.

\title{
Z.N.(S.) 1105.
}

In the period between the first presentations of these proposals in 1956 and now, the name Cratena seems to have been established in such a manner that further confusion does not appear likely, and there is no gain any more in suppressing it. Consequently, I accept the proposals from Mr. Heppell and Dr. Burns to preserve it.

The family name, however, makes trouble. Evidently Bergh's CRATENINAE in 1892 (: 1021) containing a.o. "Cratena" and "Hervia" (both misinterpreted) is given for the CUTHONIDAE and not for the group containing the genus Rizzolia. As, in Carus (1889 : 209), Bergh mentions the sole genus "Hervia " under the sub-family CRATENINAE, there is no doubt that this family name cannot be transferred to its correct position except under the plenary powers. However, I am in some doubt whether it is appropriate to introduce that name on the Official List. It will be of use if it proves to cover a taxon different from the FAVORININAE to which Bergh referred the genus Rizzolia. Maybe, we had better drop that family name problem for the time being, which is therefore now my proposal.

\section{Z.N.(S.) 1106.}

Apparently, Dr. Burns agrees with me in the whole of this application, and I am glad to have his additional remarks. Mr. Heppell raises a single point, namely that of Diaphoreolis. Two points of view may be applied in such cases. The one is what to do if nothing ever arises. Shall we then accept in the meantime Diaphoreolis as a senior synonym to Catriona. Such a solution does not appeal to me, and I prefer the suppression of Diaphoreolis for the sake of stability. The other view is to ask what to do if really such a separate genus proved to exist. The answer is simple: Describe it again. It is possible even to suppress the names for both the purposes of priority and homonymy and, if so, even the same name can be used again-though with a new author and date (which would seem reasonable as the original authors have done nothing of real value in this case). If Mr. Heppell would like to make such a proposal, I should not protest.

\section{Z.N.(S.) 1102}

\section{FURTHER COMMENTS BY MR. HEPPELL}

Dr. Lemche's reply is valuable for shedding further light on the existing state of confusion about the genus Eubranchus. Now that he has so clearly pointed out the distinguishing criteria of the two groups involved, has shown that tricolor (=viridula) is a species quite distinct from the others, and that the other species of "Eubranchus" auctt. are referable to Capellinia, I see no reason why Eubranchus (in the restricted sense) and tricolor should not be placed on the appropriate Official Lists. I am, 
therefore, still in favour of retaining Eubranchus for the group of E. tricolor and using either Capellinia, based on capellinii (=cingulata), or Amphorina, based on alberti (=farrani), for the remaining species.

\section{Z.N.(S.) 1106.}

I now agree with Dr. Lemche that it would be better to suppress the name Diaphoreolis as a nomen dubium, and redescribe the genus if it should subsequently be rediscovered. With regard to his final suggestion, though, it seems to me that if the original name were to be suppressed for the purposes of both priority and homonymy, the name would still date from the first subsequent validation and such an action would not therefore serve any real purpose.

SUPPORT FOR PROPOSAL TO SUPPRESS GENERIC NAMES TANAGRA LINNAEUS, 1764, AND TANAGRA LINNAEUS, 1766; AND TO PLACE EUPHONIA DESMAREST, 1806, ON THE OFFICIAL LIST OF GENERIC NAMES IN ZOOLOGY (AVES)

(see volume 20, pages 296-302, volume 21, pages 23)

By Eugene Eisenmann (The American Museum of Natural History, New York, U.S.A.)

The present Standing Committee on Ornithological Nomenclature of the International Ornithological Congress has previously submitted a recommendation on this question supporting Proposal $B$. (Those originally supporting Proposal $A$ have withdrawn their application.) As a Member of the present S.C.O.N., I joined in the recommendation; here I wish only to emphasize an argument based on experience as a specialist in neotropical birds.

Aside from disputed applicability, the main reason for suppressing Tanagra for the large genus commonly called euphonias is the confusion with the almost identical name of another large genus of the same family (Thraupidae) currently called Tangara Brisson, 1760. Confusion between these two names is not restricted to printers and stenographers; I personally know it to occur in correspondence and oral discussion between ornithologists. The confusion is compounded by the fact that two tanagers with overlapping ranges in Colombia, Ecuador, Peru, Bolivia, Venezuela and Brazil, currently bear the names Tanagra xanthogaster and Tangara xanthogastra (see de Schauensee, Birds of Colombia, pp. 354, 359, 1964). The easiest way to remove the confusion is to suppress the Linnaean names Tanagra 1764 and 1766, thus restoring as the senior name Euphonia Desmarest, used for so long that it became and remains the common name of the group.

Conformity with a common name is no reason, of course, for suppressing a valid scientific name, but the circumstances that a long used scientific name has become the accepted venacular name is a consideration in weighing whether a proposed use of the plenary powers for other reasons will cause undue inconvenience. Here reversion to former usage by reinstatement of Euphonia will be easy because the birds are called euphonias.

\section{By B. P. Hall (British Museum (Natural History), London)}

I would like to support Proposal B put forward by Prof. Mayr and Dr. Storer (p. 301), for the reasons given, and particularly since Proposal A met with opposition from American ornithologists, since they are the ones most intimately concerned

Bull. zool. Nomencl., Vol. 22, Part 1. April 1965. 


\section{$2 \mathrm{BHL}$ Biodiversity Heritage Library}

Heppell, D. 1965. "Further comments." The Bulletin of zoological nomenclature 22, 11-12. https://doi.org/10.5962/bhl.part.11035.

View This Item Online: https://www.biodiversitylibrary.org/item/44464

DOI: https://doi.org/10.5962/bhl.part.11035

Permalink: https://www.biodiversitylibrary.org/partpdf/11035

\section{Holding Institution}

Natural History Museum Library, London

\section{Sponsored by}

Natural History Museum Library, London

\section{Copyright \& Reuse}

Copyright Status: In copyright. Digitized with the permission of the rights holder.

License: http://creativecommons.org/licenses/by-nc-sa/3.0/

Rights: https://biodiversitylibrary.org/permissions

This document was created from content at the Biodiversity Heritage Library, the world's largest open access digital library for biodiversity literature and archives. Visit BHL at https://www.biodiversitylibrary.org. 